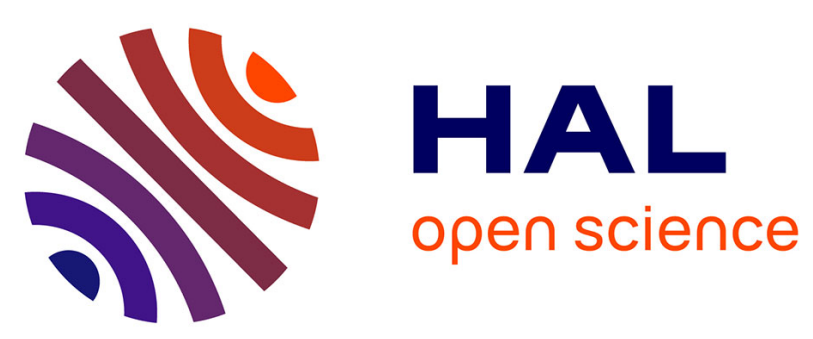

\title{
Rhodium(III)-Catalyzed C-H \\ Activation/Heterocyclization as a Macrocyclization Strategy. Synthesis of Macrocyclic Pyridones
}

Jean-Philippe Krieger, Dominique Lesuisse, Gino Ricci, Marc-Antoine Perrin, Christophe Meyer, Janine Cossy

\section{To cite this version:}

Jean-Philippe Krieger, Dominique Lesuisse, Gino Ricci, Marc-Antoine Perrin, Christophe Meyer, et al.. Rhodium(III)-Catalyzed C-H Activation/Heterocyclization as a Macrocyclization Strategy. Synthesis of Macrocyclic Pyridones. Organic Letters, 2017, 19 (10), pp.2706-2709. 10.1021/acs.orglett.7b01051 . hal-03230690

\section{HAL Id: hal-03230690 https://hal.science/hal-03230690}

Submitted on 8 Jul 2021

HAL is a multi-disciplinary open access archive for the deposit and dissemination of scientific research documents, whether they are published or not. The documents may come from teaching and research institutions in France or abroad, or from public or private research centers.
L'archive ouverte pluridisciplinaire HAL, est destinée au dépôt et à la diffusion de documents scientifiques de niveau recherche, publiés ou non, émanant des établissements d'enseignement et de recherche français ou étrangers, des laboratoires publics ou privés. 


\title{
Rhodium(III)-Catalyzed C-H Activation/Heterocyclization as a Macrocyclization Strategy. Synthesis of Macrocyclic Pyridones
}

\author{
Jean-Philippe Krieger, ${ }^{\dagger}$ Dominique Lesuisse, ${ }^{\ddagger}$ Gino Ricci, ${ }^{\ddagger}$ Marc-Antoine Perrin,${ }^{\S}$ Christophe Meyer ${ }^{\dagger *}$ \\ and Janine Cossy ${ }^{\dagger} *$
}

${ }^{\dagger}$ Laboratoire de Chimie Organique, Institute of Chemistry, Biology and Innovation (CBI), ESPCI Paris, CNRS (UMR8231), PSL Research University, 10 rue Vauquelin, 75231 Paris Cedex 05, France

${ }^{\ddagger}$ R\&D Sanofi, 1 Avenue Pierre Brossolette, 91382 Chilly-Mazarin Cedex, France

${ }^{\text {F}}$ Sanofi Process Development, 45 Chemin de Mételine BP15, 04210 Sisteron Cedex, France

${ }^{\S}$ R\&D Sanofi, 13 Quai Jules Guesde, 94403 Vitry-sur-Seine Cedex, France

Supporting Information Placeholder
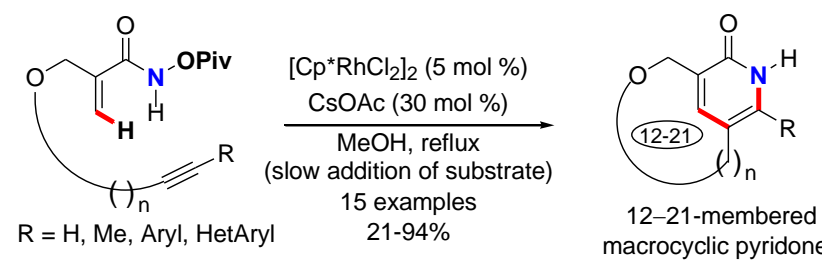

12-21-membered macrocyclic pyridones

ABSTRACT: Structurally diverse macrocyclic pyridones can be efficiently synthesized by a rhodium(III)-catalyzed C-H activation/heterocyclization of $\omega$-alkynyl $\alpha$-substituted acrylic hydroxamates. The use of a $O$-pivaloyl hydroxamate as directing group was crucial to achieve efficient catalyst turnover in a redox-neutral process.

Transition metal-catalyzed reactions proceeding with $\mathrm{C}-\mathrm{H}$ activation constitute a class of transformations that have tremendously impacted the field of organic synthesis and provided new opportunities for constructing heterocycles in an atomand step-economic manner. ${ }^{1}$ In recent years, macrocycles have aroused considerable interest in medicinal chemistry because these compounds can be potentially used as probes or drugs to target protein-protein interactions. ${ }^{2}$ Within the quest for innovative strategies toward structurally diverse macrocycles, activation of $\mathrm{C}-\mathrm{H}$ bonds can be of interest, compared to conventional macrocyclizations of $\alpha, \omega$-difunctionalized acyclic precursors, although examples are still scarce. ${ }^{3}$ Macrolactones A have been prepared by intramolecular palladium-catalyzed $\mathrm{C}-\mathrm{H}$ allylic oxidation, ${ }^{4}$ or rhodium-catalyzed redox-neutral C$\mathrm{H}$ propargylic oxidation, ${ }^{5}$ whereas intramolecular palladiumcatalyzed $\mathrm{C}-\mathrm{H}$ arylations or heteroarylations have been used to construct macrocycles $\mathbf{B} .^{6,7}$ Recently, aza-macrocycles $\mathbf{C}$ have been synthesized by an intramolecular rhodium-catalyzed amination (Scheme 1). ${ }^{8,9} \mathrm{We}$ previously reported an intramolecular version of the ruthenium(II)-catalyzed heterocyclization of benzhydroxamates with alkynes, ${ }^{10,11}$ applied to substrates $\mathbf{D}$, that allowed an efficient access to macrocyclic isoquinolones $\mathbf{E}$ (Scheme 1, eq 1). ${ }^{12}$ Compared to the intermolecular redox-neutral process which normally operates in the case of benzhydroxamates ( $\mathrm{N}-\mathrm{O}$ cleavage), ${ }^{10,11}$ the presence of an external oxidant such as $\mathrm{Cu}(\mathrm{OAc})_{2},{ }^{13}$ in conjunction with the portionwise addition of $\omega$-alkynyl benzhydroxamates $\mathbf{D}$, were crucial to ensure catalyst turnover. ${ }^{12}$ To expand the scope of macrocyclizations proceeding with $\mathrm{C}-\mathrm{H}$ activation and formation of a heterocyclic scaffold, pyridones emerged as appealing targets because of their wide occurrence in bioactive compounds. ${ }^{14}$

Herein, we report our investigations on the development of the rhodium(III)-catalyzed macrocyclization of $\omega$-alkynyl $\alpha$-substituted acrylic hydroxamates $\mathbf{F}$ into macrocyclic pyridones $\mathbf{H},{ }^{15}$ occurring through metallacycle intermediates G and a redox-neutral process (Scheme 1, eq 2).

\section{Scheme 1. Macrocyclization by $\mathrm{C}-\mathrm{H}$ Activation}

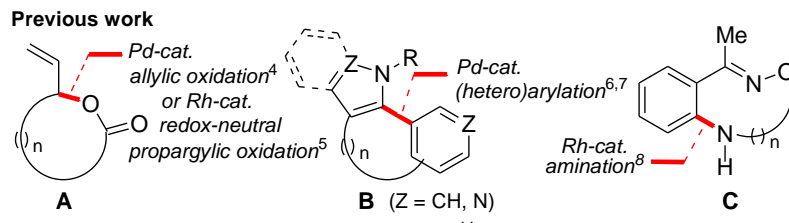

$R u(I I)$-catalyzed $\mathrm{C}-\mathrm{H}$ activation/heterocyclization ${ }^{11}$
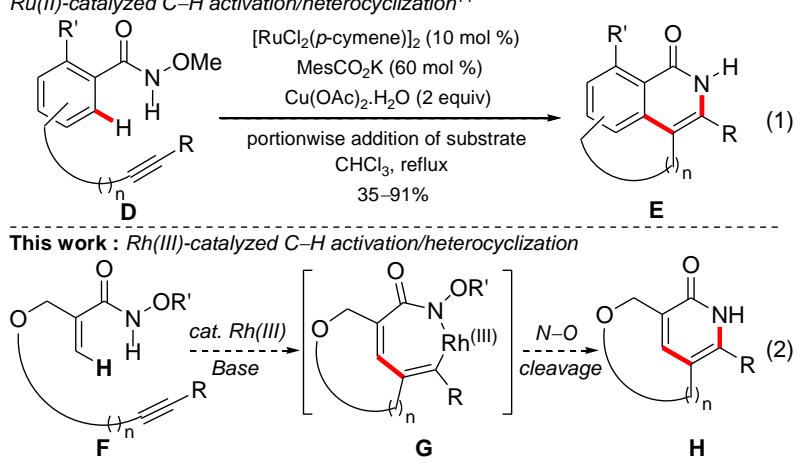
Acrylic hydroxamates $\mathbf{F}$, which should allow for milder reaction conditions than acrylamides, ${ }^{15}$ were selected as substrates and our studies began by investigating the reactivity of $\omega$-alkynyl $O$-methyl hydroxamate 1 . Under the conditions of the ruthenium(II)-catalyzed macrocyclization, previously tuned-up for benzhydroxamates D $\left\{\left[\mathrm{RuCl}_{2}(p \text {-cymene })\right]_{2}\right.$ $(10 \mathrm{~mol} \%), \mathrm{MesCO}_{2} \mathrm{~K}(60 \mathrm{~mol} \%), \mathrm{Cu}(\mathrm{OAc})_{2} \cdot \mathrm{H}_{2} \mathrm{O}$ (2 equiv), $\mathrm{CHCl}_{3}$ (final concentration, $c 0.02 \mathrm{M}$ ), reflux $\},{ }^{12}$ conversion of substrate 1 into the desired macrocyclic pyridone $\mathbf{2}$ was extremely sluggish. The best result was obtained by achieving a slow addition of $\mathbf{1}$ (portionwise over $5 \mathrm{~h}$ ) but macrocyclic pyridone 2 was isolated in $35 \%$ yield only, despite complete conversion of the substrate. ${ }^{12}$ The use of a rhodium(III) catalyst $^{11}$ was immediately considered and we observed that the slow addition of 1 (via syringe pump over $0.5 \mathrm{~h}$ ) to a solution of $\left[\mathrm{Cp}^{*} \mathrm{RhCl}_{2}\right]_{2}(5 \mathrm{~mol} \%)$ and CsOAc $(30 \mathrm{~mol} \%)$ in $\mathrm{MeOH}$ (reflux, $0.75 \mathrm{~h}$ ) led to complete conversion and afforded the 12-membered pyridone $\mathbf{2}$ in $67 \%$ isolated yield (Scheme 2).

Scheme 2. Ru(II)- and Rh(III)-Catalyzed Macrocyclization of $O$-methyl hydroxamate 1

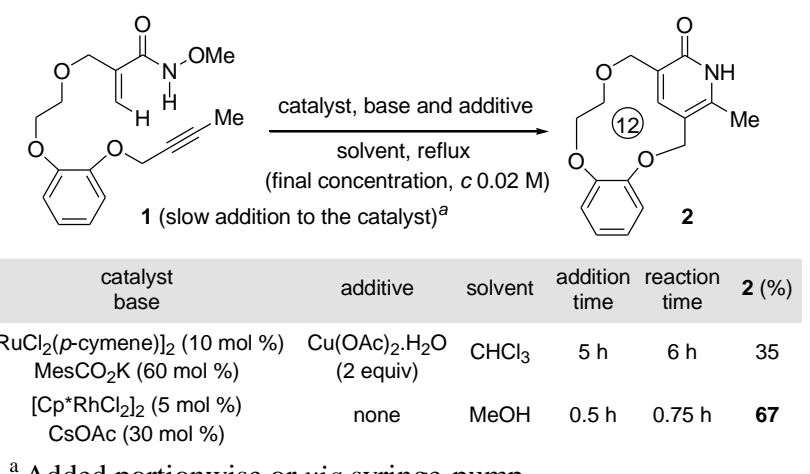

${ }^{\text {a }}$ Added portionwise or via syringe-pump.

This latter result clearly highlighted the superiority of the rhodium(III) over the ruthenium(II) catalytic system. However, the presence of a catechol linker in substrate $\mathbf{1}$ may facilitate the macrocyclization and thus the reaction conditions had to be evaluated with other substrates. Under the rhodium(III)catalyzed conditions, disappointing results were indeed obtained with $\omega$-alkynyl acryclic $O$-methyl hydroxamate $\mathbf{3}$, devoid of a catechol linker, which was not efficiently converted $(<10 \%)$ into the 14 -membered pyridone $4(5 \%)$. The catalytic activity appeared to decay rapidly, as observed in the ruthenium-catalyzed macrocyclizations in the absence of additive. ${ }^{12}$ The reaction was therefore conducted in the presence of $\mathrm{Cu}(\mathrm{OAc})_{2} \cdot \mathrm{H}_{2} \mathrm{O}(50 \mathrm{~mol} \%)^{11 \mathrm{~g}, 13}$ and this latter additive restored the catalytic activity as a complete conversion of substrate $\mathbf{3}$ occurred. However, the isolated yield of pyridone $\mathbf{4}$ was modest $(28 \%)$ because the major product was the $N$-methoxy ana$\log 5(55 \%)$, which has to be inconveniently separated by flash chromatography. Thus, during the intramolecular heterocyclization of $\omega$-alkynyl hydroxamate $3, \mathrm{Cu}(\mathrm{OAc})_{2}$ not only helps to regenerate the $\mathrm{Rh}(\mathrm{III})$ catalyst by assisting the reductive elimination/ $\mathrm{N}-\mathrm{O}$ bond cleavage (redox-neutral process) ${ }^{13}$ leading to pyridone $\mathbf{4}$, but also oxidizes $\mathrm{Rh}(\mathrm{I})$ species by an outer-sphere mechanism after the release of $N$-methoxy pyridone $\mathbf{5}$ in the reaction medium. Fagnou et al. previously showed that a $O$-pivaloyl hydroxamate could behave as a more reactive directing group and internal oxidant than the
$O$-methyl analog, thereby allowing for milder reaction conditions and a wider substrate scope. ${ }^{11 \mathrm{f}}$ This modification of the hydroxamate substituents has a spectacular effect on the efficiency of the rhodium(III)-catalyzed macrocyclization, as illustrated in the case of $O$-pivaloyl substrate $\mathbf{6}$ which afforded pyridone 4 in $74 \%$ yield, in the absence of additive. ${ }^{16}$ The macrocyclization of hydroxamate 7 , possessing a terminal alkyne, ${ }^{11 \mathrm{f}}$ was also remarkably efficient as the 14-membered disubstituted pyridone $\mathbf{8}$ was isolated in $94 \%$ yield in a reaction conducted at the gram-scale (Scheme 3 ).

\section{Scheme 3. Comparison of the Reactivity of $O$-methyl and $O$-pivaloyl hydroxamates}

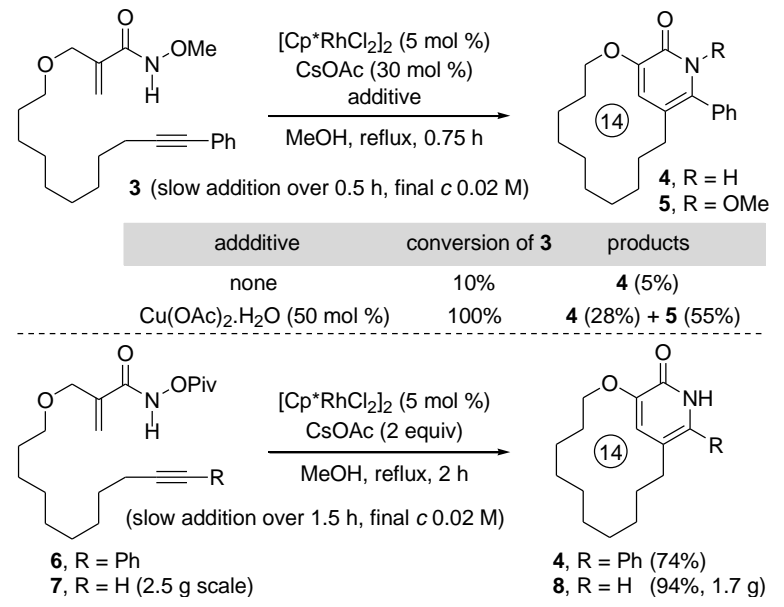

It is worth mentioning that a minor regioisomeric pyridone 4' $\left(\mathbf{4} / \mathbf{4}^{\prime}=80: 20\right)$ was detected by NMR analysis of the crude material arising from the macrocyclization of $O$-pivaloyl hydroxamate $\mathbf{6}$, and this latter by-product was isolated in $15 \%$ yield (Scheme 4). ${ }^{17}$ In the commonly accepted (simplified) mechanism, ${ }^{10}$ rhodacycle [Rh]-1 arising from a concerted metalation-deprotonation of $\mathbf{6}$ directed by the hydroxamate, would undergo migratory insertion of the alkyne to generate complex [Rh]-2. Reductive elimination and insertion of the metal into the $\mathrm{N}-\mathrm{O}$ bond would produce complex [Rh]-3 and release the $\mathrm{Rh}(\mathrm{III})$ catalyst and pyridone 4 . $\mathrm{A} \mathrm{Rh}(\mathrm{V})$ nitrene, $[\mathrm{Rh}]-4$, may also be involved as an intermediate. ${ }^{18}$ If migratory

Scheme 4. Formation of Regioisomeric Pyridones 4 and 4'

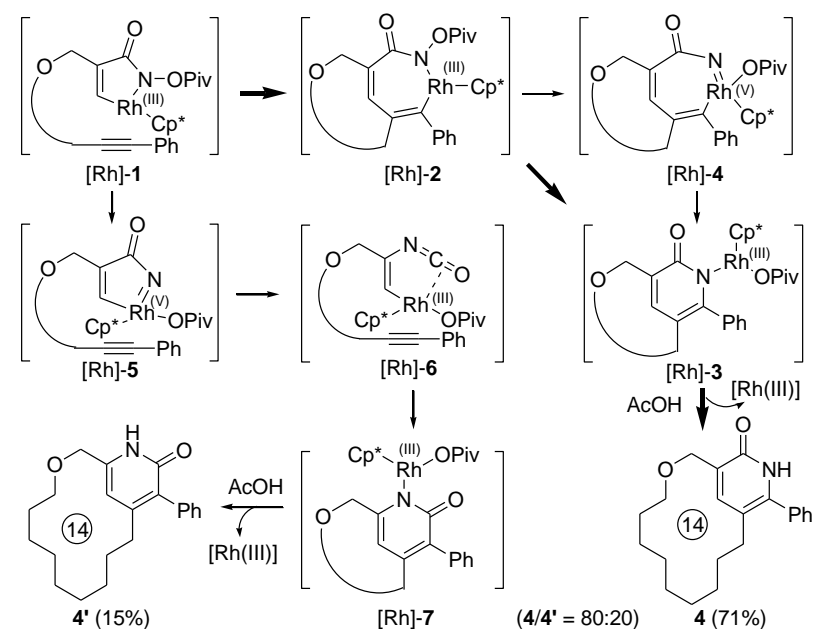


insertion of the alkyne is retarded, as it may be the case in macrocyclizations, rhodacycle [Rh]-1 may evolve into the $\mathrm{Rh}(\mathrm{V})$ nitrene $[\mathrm{Rh}]-5^{18}$ which would undergo rearrangement into $\mathrm{Rh}(\mathrm{III})$ isocyanate complex [Rh]-6. Subsequent migratory insertion of the alkyne and of the isocyanate would ultimately produce complex [Rh]-7, thereby accounting for the observation of pyridone 4' (Scheme 4). Although the formation of regioisomeric pyridones such as 4', arising from an apparent hydroxamate-isocyanate rearrangement followed by heterocyclization, ${ }^{19}$ was generally a minor side process in most of the other examples of rhodium-catalyzed macrocyclizations investigated, this observation was noteworthy.

The macrocyclization of $\omega$-alkynyl acrylic hydroxamates $\mathbf{9 a - 9 j}$, devoid of a catechol linker and possessing different aryl and heteroaryl susbtituents on the alkyne, was then studied. In all cases, complete conversions were observed. Pyridone 10a, arising from the phenyl-substituted alkyne 9a, was isolated in excellent yield $(86 \%)$. For substrates $9 \mathbf{b}-9 \mathbf{e}$, we noticed that the more electron-withdrawing the substituent at the para position of the aromatic ring, the lower the yield of the corresponding pyridones 10b-10e. This trend was apparent from the formation of $\mathbf{1 0 b}(72 \%)$ and 10c $(64 \%)$, substituted respectively by a bromine atom or a $\mathrm{CF}_{3}$ group, both having a negative inductive effect, and pyridones 10d (59\%) and 10e (44\%) bearing strongly attractive mesomeric acetyl and nitro groups. Conversely, pyridones $10 f(77 \%)^{20}$ or $\mathbf{1 0 g}(78 \%)$, possessing a mesomeric donor methoxy substituent at the para or the ortho position of the aromatic ring, were obtained in higher yields. These latter results were in agreement with previous observations that electron-rich diaryl alkynes are preferred partners in the $\mathrm{Rh}$ (III)-catalyzed hetero-cyclization of benzamides whilst the opposite trend is observed in the $\mathrm{Ru}(\mathrm{II})$-catalyzed process. ${ }^{10,11}$ The behavior of heteroaryl-substituted alkynes $9 \mathbf{9}-\mathbf{9 j}$ was next explored. Although pyridones 10h (21\%) and 10i (41\%) possessing 2-thienyl and 6-chloropyridin-2-yl substituents, respectively, were isolated in modest yields, substrate $\mathbf{9 j}$ armed with the electron-rich $N$-Boc indolyl group led to macrocyclic pyridone $\mathbf{1 0 j}$ in $81 \%$ yield (Scheme 5).

\section{Scheme 5. Synthesis of 12-membered Pyridones 10a-10j}

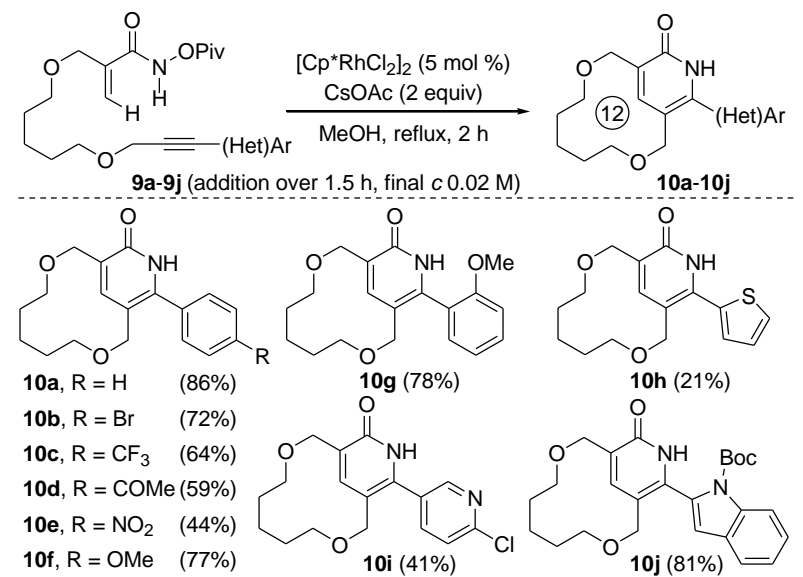

A nitrogen atom can be incorporated within the chain, as illustrated by the macrocyclization of carbamate $\mathbf{1 1}$ leading to the 12-membered aza-macrocyclic pyridone 12 (81\%) (Scheme 6, eq 1). Macrocycles of larger ring-sizes and pos- sessing an additional heterocyclic scaffold seem also accessible by this strategy, as exemplified by the macrocyclization of 13 incorporating a triazole, which afforded the 21-membered pyridone 14 (32\%) (Scheme 6, eq 2). Although the yield is modest, this latter result illustrates that the combination of a copper-catalyzed azide-alkyne cycloaddition for the preparation of acyclic $\omega$-alkynyl acrylic hydroxamates and the rhodium-catalyzed cyclization may constitute an interesting approach toward diversely substituted macrocyclic pyridones.

\section{Scheme 6. Synthesis of Macrocyclic Pyridones 12 and 14}

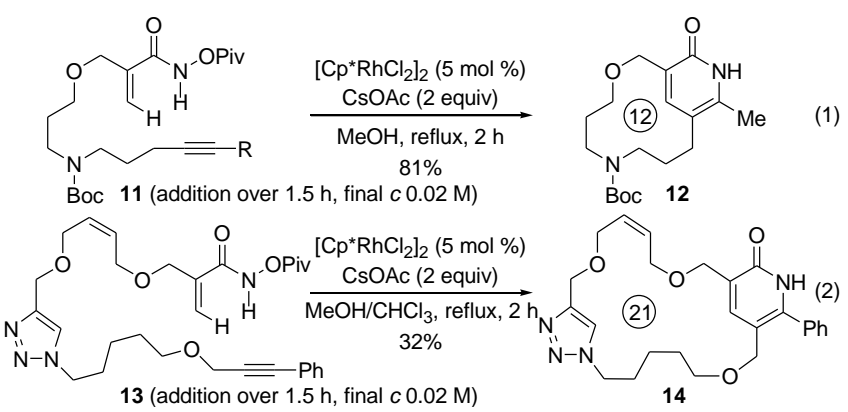

Pyridones can also be used as precursors of substituted pyridines, which are arguably the most encountered heterocycles in drugs. ${ }^{21}$ To that effect, pyridone $\mathbf{4}$ was converted into heteroaryl triflate $15(94 \%)^{20}$ which was subsequently involved in an aromatic nucleophilic substitution with aminoacetaldehyde dimethyl acetal to produce the 14-membered tetrasubstituted aminopyridine 16 (68\%). Triflate 15 was also engaged in a Suzuki-Miyaura coupling with 2-methoxyphenylboronic acid and the 14-membered meta-pyridinophane 17 was isolated in $74 \%$ yield (Scheme 7).

\section{Scheme 7. Synthesis of Macrocyclic Pyridines 16 and 17}

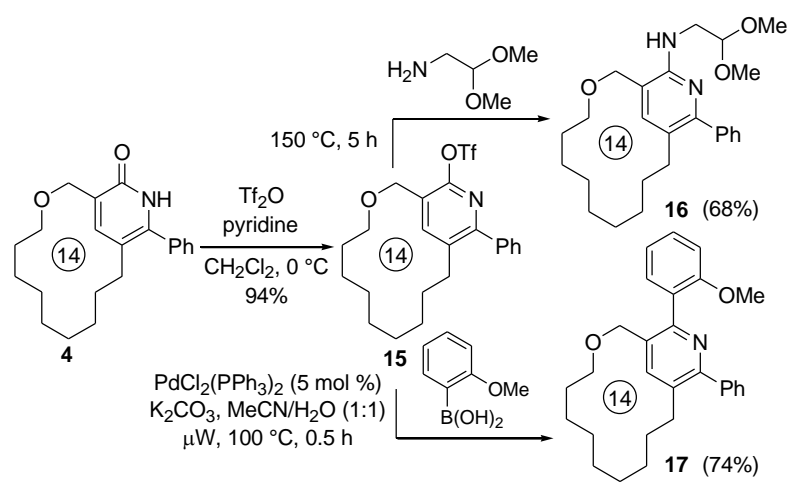

In conclusion, we have demonstrated that the rhodium(III)catalyzed macrocyclization of $\omega$-acetylenic $\alpha$-substituted acrylic hydroxamates, proceeding with $\mathrm{C}-\mathrm{H}$ activation and intramolecular heterocyclization, can lead to structurally diverse 12 - to 21-membered macrocyclic pyridones in moderate to excellent yields. The use of a $O$-pivaloyl hydroxamate as directing group was crucial to ensure efficient catalyst turnover in a redox-neutral process. These results contribute to further expand the scope of macrocyclizations proceeding with $\mathrm{C}-\mathrm{H}$ activation and enabling formation of heterocyclic scaffolds of utmost importance in agrochemistry or medicinal chemistry. 


\section{ASSOCIATED CONTENT}

\section{Supporting Information}

The Supporting Information is available free of charge on the ACS Publications website.

Experimental procedures, characterization for all products, copies of the NMR spectra (PDF) and cif files.

\section{AUTHOR INFORMATION}

\section{Corresponding Author}

* E-mail: christophe.meyer@espci.fr, janine.cossy@espci.fr

\section{ACKNOWLEDGMENT}

One of us (J.-P. K.) thanks Sanofi for a PhD grant.

\section{REFERENCES}

(1) (a) Moselage, M.; Li, J.; Ackermann, L. ACS Catal. 2016, 6, 498-525. (b) Gulías, M.; Mascareñas, J. L. Angew. Chem., Int. Ed. 2016, 55, 11000-11019. (c) Guo, X.-X.; Gu, D.-W.; Wu, Z.; Zhang, W. Chem. Rev. 2015, 115, 1622-1651. (d) Wencel-Delord, J.; Glorius, F. Nat. Chem. 2013, 5, 369-375. (e) Chen, D. Y.-K.; Youn, S. W. Chem.-Eur. J. 2012, 18, 9452-9474. (f) Yamaguchi, J.; Yamaguchi, A. D.; Itami, K. Angew. Chem., Int. Ed. 2012, 51, 8960-9009. (g) Kuhl, N.; Hopkinson, M. N.; Wencel-Delord, J.; Glorius, F. Angew. Chem., Int. Ed. 2012, 51, 10236-10254. (h) Arockiam, P. B.; Bruneau, C.; Dixneuf, P. H. Chem. Rev. 2012, 112, 5879-5918. (i) Song, G.; Wang, F.; Li, X. Chem. Soc. Rev. 2012, 41, 3651-3678. (j) Wencel-Delord, J.; Dröge, T.; Liu, F.; Glorius, F. Chem. Soc. Rev. 2011, 40, 4740-4761. (k) Colby, D. A.; Bergman, R. G.; Ellman, J. A Chem. Rev. 2010, 110, 624-655. (1) Satoh, T.; Miura, M. Chem.-Eur. J. 2010, 16, 11212-11222. (m) Jazzar, R.; Hitce, J.; Renaudat, A.; Sofack-Kreutzer, J.; Baudoin, O. Chem.-Eur. J. 2010, 16, 2654-2672.

(2) (a) Macrocycles in Drug Discovery, Levis, J. I., Ed.; RSC: Cambridge, 2015. (b) Yudin, A. K. Chem. Sci. 2015, 6, 30-49. (c) Giordanetto, F.; Kihlberg, J. J. Med. Chem. 2014, 57, 278-295. (d) Mallinson, J.; Collins, I. Future Med. Chem. 2012, 4, 1409-1438. (e) Marsault, E.; Peterson, M. L. J. Med. Chem. 2011, 54, 1961-2004. (f) Driggers, E. M.; Hale, S. P.; Lee, J.; Terrett, N. K. Nat. Rev. Drug Discov. 2008, 7, 608-624.

(3) Martí-Centelles, V.; Pandey, M. D.; Burguete, M. I.; Luis, S. V. Chem. Rev. 2015, 115, 8736-8834.

(4) (a) Fraunhoffer, K. J.; Prabagaran, N.; Sirois, L. E.; White, M. C. J. Am. Chem. Soc. 2006, 128, 9032-9033. (b) Stang, E. M.; White, M. C. Nat. Chem. 2009, 1, 547-551. (c) Stang, E. M.; White, M. C. Angew. Chem., Int. Ed. 2011, 50, 2094-2097.

(5) Lumbroso, A.; Abermil, N.; Breit, B. Chem. Sci. 2012, 3, 789793.

(6) (a) Dong, H.; Limberakis, C.; Liras, S.; Price, D.; James, K. Chem. Commun. 2012, 48, 11644-11646. (b) Mendive-Tapia, L.; Preciado, S.; García, J., Ramón, R., Kielland, N., Albericio, F., Lavilla, R. Nat. Commun. 2015, 6, 7160-7168.

(7) Johnson, T. W.; Richardson, P. F.; Bailey, S.; Brooun, A.; Burke, B. J.; Collins, M. R.; Cui, J. J.; Deal, J. G.; Deng, Y.-L.; Dinh, D.; Engstrom, L. D.; He, M.; Hoffman, J.; Hoffman, R. L.; Huang, Q.; Kania, R. S.; Kath, J. C.; Lam, H.; Lam, J. L.; Le, P. T.; Lingardo, L.; Liu, W.; McTigue, M.; Palmer, C. L.; Sach, N. W.; Smeal, T.; Smith, G. L.; Stewart, A. E.; Timofeevski, S.; Zhu, H.; Zhu, J.; Zou, H. Y.; Edwards, M. P. J. Med. Chem. 2014, 57, 4720-4744.

(8) Kim, H.; Chang, S. Angew. Chem., Int. Ed. 2017, 56, 33443348.

(9) One example of $\mathrm{Mn}(\mathrm{I})$-catalyzed indole alkynylation leading to a 21-membered macrocycle was recently reported, see: Ruan, Z; Sauermann, N.; Manoni, E.; Ackermann, L. Angew. Chem., Int. Ed. 2017, 56, 3172-3176.
(10) For $\mathrm{Ru}(\mathrm{II})$-catalyzed alkyne-benzamide heterocyclizations, see: (a) Ackermann, L.; Lygin, A. V.; Hoffmann, N. Angew. Chem., Int. Ed. 2011, 50, 6379-6382. (b) Deponti, M.; Kozhushkov, S. I.; Yufit, D. S.; Ackermann, L. Org. Biomol. Chem. 2013, 11, 142-148. For an intramolecular version with a $N$-tethered alkyne, see: (c) Swamy, T.; Maheshwar Rao, B.; Yadav, J. S.; Ravinder, V.; Sridhar, B.; Subba Reddy, B. V. RSC Adv. 2015, 5, 68510-68514. For reactions involving benzhydroxamates, see: (d) Ackermann, L.; Fenner, S. Org. Lett. 2011, 13, 6548-6551. (e) Li, B.; Feng, H.; Xu, S.; Wang, B. Chem.-Eur. J. 2011, 17, 12573-12577. (f) Yang, F.; Ackermann, L. J. Org. Chem. 2014, 79, 12070-12082.

(11) For Rh(III)-catalyzed alkyne-benzamide heterocyclizations, see: (a) Hyster, T. K.; Rovis, T. J. Am. Chem. Soc. 2010, 132, 1056510569. (b) Mochida, S.; Umeda, N.; Hirano, K.; Satoh, T.; Miura, M. Chem. Lett. 2010, 39, 744-746. (c) Song, G.; Chen, D.; Pan, C.-L.; Crabtree, R. H.; Li, X. J. Org. Chem. 2010, 75, 7487-7490. For an intramolecular version with a $N$-tethered alkyne, see: (d) Quiñones, N.; Seoane, A.; García-Fandiño, R.; Mascareñas, J. L.; Gulías, M. Chem. Sci. 2013, 4, 2874-2879. For reactions involving benzhydroxamates, see: (e) Guimond, N.; Gouliaras, C.; Fagnou, K. J. Am. Chem. Soc. 2010, 132, 6908-6909. (f) Guimond, N.; Gorelsky, S. I.; Fagnou, K. J. Am. Chem. Soc. 2011, 133, 6449-6457. (g) Wang, H.; Grohmann, C.; Nimphius, C.; Glorius, F. J. Am. Chem. Soc. 2012, 134, 19592-19595. (h) Xu, X.; Liu, Y.; Park, C.-M. Angew. Chem., Int. Ed. 2012, 51, 9372-9376. (i) Fukui, Y.; Liu, P.; Liu, Q.; He, Z.-T.; Wu, N.-Y.; Tian, P.; Lin, G.-Q. J. Am. Chem. Soc. 2014, 136, $15607-15614$.

(12) Krieger, J.-P.; Ricci, G.; Lesuisse, D.; Meyer, C.; Cossy, J. Chem.-Eur. J. 2016, 22, 13469-13473.

(13) For a theoretical investigation on the role of $\mathrm{Cu}(\mathrm{OAc})_{2}$, see: Zhao, L.; Fang, D.-C. Eur. J. Org. Chem. 2015, 4772-4781.

(14) (a) Bai, D. L.; Tang, X. C.; He, X. C. Curr. Med. Chem. 2000, 7, 355-374. (b) Mitscher, L. A. Chem. Rev. 2005, 105, 559-592. (c) Torres, M.; Gil; S.; Parra, M. Curr. Org. Chem. 2005, 9, 1757-1779.

(15) For $\mathrm{Rh}(\mathrm{III})$ - or $\mathrm{Ru}(\mathrm{II})$-catalyzed acrylamide-alkyne heterocyclizations, see ref. $11 \mathrm{~h}$ and: (a) Su, Y.; Zhao, M.; Han, K.; Song, G.; Li, X. Org. Lett. 2010, 12, 5462-5465. (b) Hyster, T. K.; Rovis, T. Chem. Sci. 2011, 2, 1606-1610. (c) Ackermann, L.; Lygin, A. V.; Hofmann, N. Org. Lett. 2011, 13, 3278-3281. For one example of a Co-catalyzed process, see: (d) Grigorjeva, L.; Daugulis, O. Angew. Chem., Int. Ed. 2014, 53, 10209-10212. For a recently disclosed Fe-catalyzed process, see: (e) Matsubara, T.; Ilies, L.; Nakamura, E. Chem.-Asian J. 2016, 11, 380-384.

(16) Complete conversion of $\mathbf{6}$ was observed in the presence of $\left[\mathrm{RuCl}_{2}(p \text {-cymene })\right]_{2} \quad(10 \mathrm{~mol} \%), \quad \mathrm{MesCO}_{2} \mathrm{~K} \quad(60 \mathrm{~mol} \%) \quad\left(\mathrm{CHCl}_{3}\right.$, addition of substrate over $2 \mathrm{~h}$ ) but a complex mixture of products was formed. Catalysts based on cheaper metals than rhodium were not further considered in this study.

(17) The structure of $\mathbf{4}$ and 4' was assigned by X-ray diffraction analysis of the corresponding regioisomeric triflates $\mathbf{1 5}$ and 15', see Supporting Information.

(18) For mechanistic studies on $\mathrm{Rh}(\mathrm{III})$-catalyzed $\mathrm{C}-\mathrm{H}$ mediated heterocyclizations, see: (a) Yang, Y.-F.; Houk, K. N.; Wu, Y.-D. J. Am. Chem. Soc. 2016, 138, 6861-6868. (b) Chen, J.; Guo, W.; Xia, Y. J. Org. Chem. 2016, 81, 2635-2638. (c) Li, J.; Qiu, Z. J. Org. Chem. 2015, 80, 10686-10693. (d) Xu, L.; Zhu, Q.; Huang, G.; Cheng, B.; Xia, Y. J. Org. Chem. 2012, 77, 3017-3024.

(19) An initial Lossen rearrangement of 6 prior to $\mathrm{C}-\mathrm{H}$ activation, which is normally directed by the hydroxamate, seems unlikely to explain the formation of 4 '.

(20) CCDC 1542219 (10f), 1542220 (15) and 1542221 (15') contain supplementary crystallographic data for this paper. These data can be obtained free of charge from the Cambridge Crystallographic Data Centre via www.ccdc.cam.ac.uk/data_request/cif.

(21) (a) Taylor, R. D.; MacCoss, M.; Lawson, A. D. G. J. Med. Chem. 2014, 57, 5845-5859. (b) Hill, M. D. Chem.-Eur. J. 2010, 16, 12052-12062 and references therein. 